Volume 41, Number $2 \quad$ Page $169 \quad$ Spring 2013

\title{
RUSH TO JUDGMENT? \\ TRIAL LENGTH AND OUTCOMES IN PATENT CASES
}

\section{Mark A. Lemley, Jamie Kendall, \& Clint Martin*}

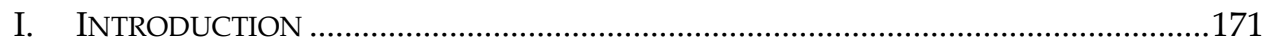

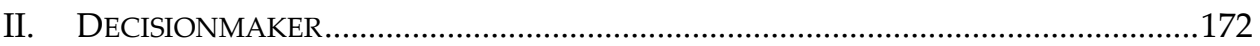

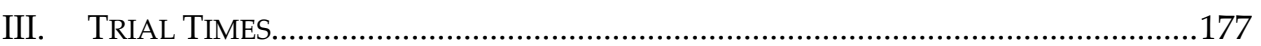

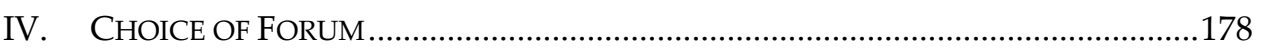

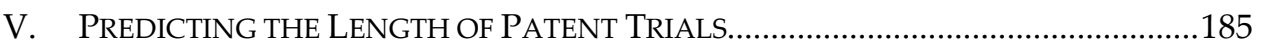

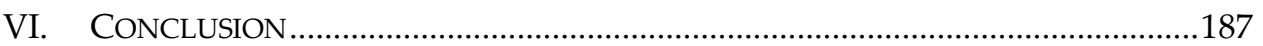

\section{LIST OF TABLES}

Table 1. National Trial Outcomes ................................................................173

Table 2. Trial Outcomes in the Eastern District of Texas ...........................179

Table 3. Trial Outcomes in the Northern District of California ................180

Table 4. Trial Outcomes in the Central District of California....................181

Table 5. Trial Outcomes in the District of Delaware ..................................183

Table 6. Trial Outcomes in the Central District of Massachusetts............184

\section{LIST OF FIGURES}

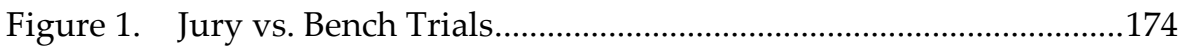

Figure 2. Decision for Patentee by Decisionmaker....................................175

Figure 3. Jury Trial Favorable to Patentee Rate by District..........................185

\footnotetext{
* (c) 2013 Mark A. Lemley, Jamie Kendall, \& Clint Martin. Mark Lemley is the William H. Neukom Professor at Stanford Law School and a partner at Durie Tangri LLP. Jamie Kendall is a J.D. candidate, Stanford Law School. Clint Martin is in the Legal Department at Google Inc. Thanks to Tim Malloy for raising the issue with us and to John Allison, Colleen Chien, Chris Cotropia, Rose Hagan, Lee Petherbridge, David Schwartz, and participants at the Empirical Patent Studies workshop at Cornell Law School for helpful comments.
} 


\section{LIST OF APPENDICES}

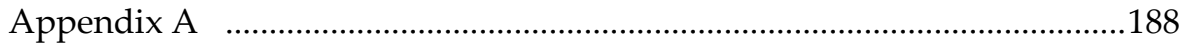

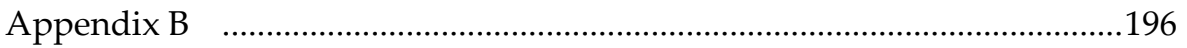

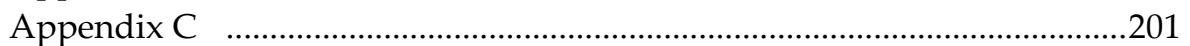




\section{INTRODUCTION}

Although the vast majority of patent cases settle before trial, the fact that a jury waits at the end of the road affects most aspects of patent litigation. The possibility of jury trial influences where parties file their cases, who they sue (and in what groups), what discovery the parties consider important to challenge, and whether particular doctrines are questions of law or questions of fact. ${ }^{1}$ In fact, most patent trials in the last decade have been before juries. ${ }^{2}$ Litigants on both sides go to great lengths to get an edge before the jury, hiring jury consultants, practicing their cases before mock juries, and choosing districts and judges based on how they will manage the case before the jury. ${ }^{3}$

For the last decade, the received wisdom in the patent bar has been that the best place for patentees to file their suit is the Eastern District of Texas. ${ }^{4}$ One of us recently challenged that wisdom in an empirical study, pointing out that the popularity of the district has slowed proceedings there considerably. ${ }^{5}$ Nevertheless, the Eastern District remains the most popular venue for patent plaintiffs because plaintiffs believe the district's juries and judicial management of cases are pro-patentee. ${ }^{6}$ Further, the Eastern District of Texas has a reputation for fast trials; ${ }^{7}$ there is a general perception in the patent bar that quick trials (especially those involving multiple defendants) favor patentees. ${ }^{8}$ Fast trials

1 See Kimberly Moore, Forum Shopping In Patent Cases: Does Geographic Choice Affect Innovation?, 79 N.C. L. REV. 889, 899-900 (2001).

2 See infra notes 11-16 and accompanying text.

3 See Moore, supra note 1, at 899.

4 See, e.g., Yan Leychkis, Of Fire Ants and Claim Construction: An Empirical Study of the Meteoric Rise of the Eastern District of Texas as a Preeminent Forum for Patent Litigation, 9 YALE J.L. \& TECH. 193, 204-05 (2007); Megan Woodhouse, Shop 'til You Drop: Implementing Federal Rules of Patent Litigation Procedure to Wear Out Forum-Shopping Patent Plaintiffs, 99 GEO. L.J. 227, 228 (2010).

5 Mark A. Lemley, Where to File Your Patent Case, 38 AIPLA Q.J. 401, 415 (2010).

$6 \quad$ See Leychkis, supra note 4 , at 206.

7 See, e.g., Tim Malloy, Trial Time in the ED Texas-One Size Fits All, Or Does It? 3 (Working Paper, 2011) (finding significant variation in the time allotted for patent trials, and noting that plaintiffs favor the Eastern District of Texas for its short trials); Woodhouse, supra note 4, at 234-35.

$8 \quad$ See Leychkis, supra note 4, at 202. 
prevent defendants from dragging the case into a technical morass of prior art. They keep the jury's attention focused on the patentee's invention, not on all the other things the defendant may have developed. And they are particularly tough for defendants in multi-defendant cases, who must share their time and can't present individual counter-narratives.

In this paper, we set out to test the conventional wisdom that short trials favor patentees. Using the Lex Machina database, ${ }^{9}$ we collected data on every patent trial conducted in the United States between January 1, 2000, and June 30, 2011. We first report outcome statistics, then we discuss the role of trial length, and finally, we consider the role of jurisdiction in driving outcomes. ${ }^{10}$

\section{DECISIONMAKER}

There were 624 patent trials leading to 679 separate judgments in the United States between January 1, 2000, and June 30, 2011. Overall, patentees won $59.9 \%$ of those trials, accused infringers won $32.9 \%$, and $7.2 \%$ resulted in split decisions. ${ }^{11}$ We report this general data in Table 1.

9 LEX MACHINA, https://lexmachina.com (last visited Apr. 1, 2013).

10 Throughout this paper, we report wins for "Claimants $(C)$ " - patenteesand "Claim Defendants (CD)" - accused infringers. We do this rather than study plaintiff and defendant wins because a significant fraction of patent suits are declaratory judgment actions in which the plaintiff is the accused infringer.

11 To win a patent case, a patentee must have a patent claim held valid and infringed. Infringement of a single valid claim was sufficient to count as a patentee win. We did not attempt to make a judgment as to whether the patentee won on most issues or assess the size of the damage award.

The mixed decisions, which we count as separate judgments, often involved two parties suing each other for patent infringement; if one party won the whole case, that was a win for that patentee but also a loss for the other patentee. Mixed decisions also frequently involved cases in which multiple patents were asserted by a single party; if one patent was held invalid or not infringed while a claim in a second patent was held valid and infringed, we deemed it a mixed decision. 
Table 1: National Trial Outcomes

\begin{tabular}{|l|l|l|l|l|l|l|}
\hline Variable & $\begin{array}{l}\text { No. of } \\
\text { Variable }\end{array}$ & $\begin{array}{l}\text { Total } \\
\text { No. }\end{array}$ & $\begin{array}{l}\% \text { of } \\
\text { Total }\end{array}$ & $\begin{array}{l}\text { Mean Time } \\
\text { (Days) }\end{array}$ & $\begin{array}{l}\text { Median } \\
\text { Time }\end{array}$ & $\begin{array}{l}\text { Standard } \\
\text { Deviation }\end{array}$ \\
\hline $\begin{array}{l}\text { Total } \\
\text { Bench }\end{array}$ & 158 & 624 & $25.3 \%$ & 5.74 & 5 & 4.22 \\
\hline $\begin{array}{l}\text { Total } \\
\text { Jury }\end{array}$ & 466 & 624 & $74.7 \%$ & 8.60 & 8 & 4.59 \\
\hline $\begin{array}{l}\text { Bench } \\
\text { for C } \\
\text { Win }\end{array}$ & 81 & 158 & $51.3 \%$ & 5.74 & 5 & 4.33 \\
\hline $\begin{array}{l}\text { Bench } \\
\text { for CD } \\
\text { Win }\end{array}$ & 67 & 158 & $42.4 \%$ & 5.40 & 5 & 4.12 \\
\hline $\begin{array}{l}\text { Bench } \\
\text { for C; } \\
\text { CD Win }\end{array}$ & 10 & 158 & $6.3 \%$ & 8.00 & 7.5 & 3.28 \\
\hline $\begin{array}{l}\text { Jury } \\
\text { Trial for } \\
\text { C Win }\end{array}$ & 293 & 466 & $62.9 \%$ & 8.32 & 7.60 & 4.60 \\
\hline $\begin{array}{l}\text { Jury } \\
\text { Trial for } \\
\text { CD Win }\end{array}$ & 138 & 466 & $29.6 \%$ & 8.87 & 8 & \\
\hline $\begin{array}{l}\text { Jury } \\
\text { Trial for } \\
\text { C; CD } \\
\text { Win }\end{array}$ & 35 & 466 & $7.5 \%$ & 9.83 & 9 & \\
\hline
\end{tabular}


Figure 1: Jury vs. Bench Trials

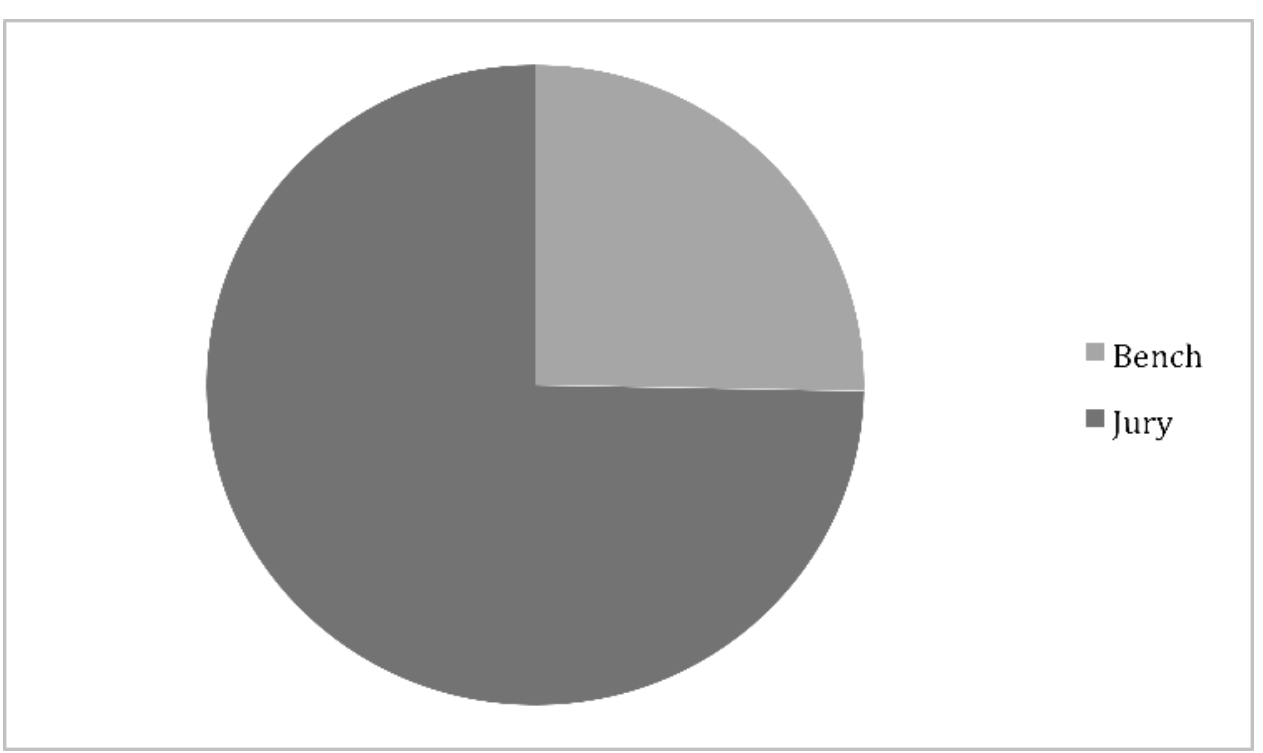

Of the 624 total trials, 466 trials, or $74.7 \%$, were tried before juries. This number may seem surprisingly low given that patentees today virtually always request juries. ${ }^{12}$ But there are certain circumstances in which juries are not an option, including patent lawsuits against the government ${ }^{13}$ and lawsuits under the Hatch-Waxman Act against generic drug manufacturers seeking only injunctive relief. ${ }^{14}$ And indeed, as we will see, districts that hear more generic pharmaceutical patent cases tend to have more bench trials. ${ }^{15}$

12 This is a very recent development; as recently as 40 years ago less than $5 \%$ of patent cases were tried to juries. See Mark A. Lemley, Why Do Juries Decide If Patents Are Valid?, _ VA. L. REV. _ (forthcoming 2014).

13 See 28 U.S.C. § 1498 (2006) (limiting the venue for patent claims against the government to the Court of Federal Claims).

14 Tegal Corp. v. Tokyo Electron Am., Inc., 257 F.3d 1331, 1339 (Fed. Cir. 2001) (holding that accused infringer has no right to jury trial where patentee requests only equitable relief and accused infringer raises only affirmative defenses). See generally Brian D. Coggio \& Timothy E. DeMasi, The Right to a Jury Trial Under The Waxman-Hatch Act: The Question Revisited and Resolved, 57 FoOD \& DRUG L.J. 155 (2002) (summarizing cases following Tegal and concluding no right to a jury trial arises in a typical Hatch-Waxman case).

15 See discussion infra Part IV. 
This data strongly supports the received wisdom that, compared to judges, juries favor patentees. ${ }^{16}$ Of the 158 bench trials, $51.3 \%$ ruled for the patentee, $42.4 \%$ for the accused infringer, and $6.3 \%$ were split decisions. By contrast, of the 466 jury trials, $62.9 \%$ ruled for the patentee, $29.6 \%$ for the accused infringer, and $7.5 \%$ were split decisions. We report the data in Figure 2.

Figure 2: Decision for Patentee by Decisionmaker

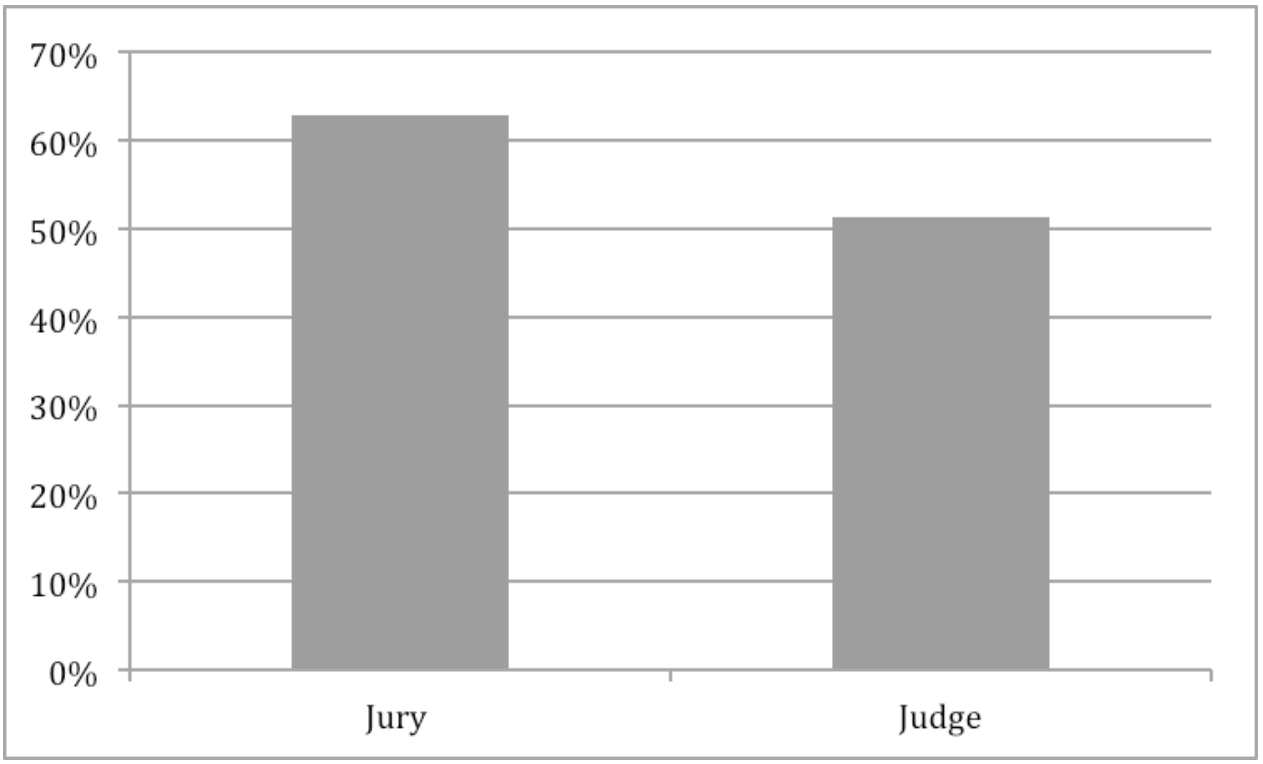

The results are also robust in the multivariate regressions. We report the various regressions in Appendix A. ${ }^{17}$ Jury trials are strongly correlated with rulings for patentees (coefficient of $-.249, \mathrm{p}=0.005$ ). ${ }^{18}$ When we exclude mixed

16 See also John R. Allison \& Mark A. Lemley, Empirical Evidence on the Validity of Litigated Patents, 26 AIPLA Q.J. 185, 212 (1998) (finding that patentees won on validity $57 \%$ of the time in bench trials and $67 \%$ before juries in cases between 1989 and 1996); Kimberly A. Moore, Judges, Juries, and Patent Cases - An Empirical Peek Inside the Black Box, 99 MicH. L. Rev. 365, 390 (2000) [hereinafter Moore, Judges, Juries, and Patent Cases] (finding that patentees won $64 \%$ of bench trials and $71 \%$ of jury trials in cases between 1983 and 1999).

17 See infra Appendix A pp. 188-95. We used single variable linear probability models in the regressions.

18 In our regression analysis, patentee wins are coded as a 1, accused infringer wins as a 3, and mixed outcomes as a 2 . A negative coefficient in the 
verdicts from the results, the findings are even stronger (coefficient of -.269, $\mathrm{p}=0.007) \cdot{ }^{19}$

One possible explanation for this strong correlation is that there is something different about bench trials. There are two types of cases where a party cannot request a jury trial: generic pharmaceutical patent disputes seeking injunctions under the Hatch-Waxman Act $^{20}$ and proceedings against the United States in the Court of Federal Claims. ${ }^{21}$ If patentees are systematically less likely to win those types of cases, the judge-jury disparity may be an artifact of these limitations. To test this, we re-ran our numbers excluding the pharmaceutical and ANDA cases. Not only did the disparity remain, it grew stronger: the coefficient grew to $-.429(\mathrm{p}=0.000)$. Patentees, then, are right to want jury trials.

Interestingly, it does not appear to matter how sophisticated the jury pool is about patents. We constructed a measure of patent-intensity by district based on the number of patents issued per capita to residents of that district. ${ }^{22}$ The most patent-intensive district is the Northern District of California, with 5.5 patents in force per thousand residents. The least patent-intensive is the District of Hawaii, with 0.3 patents per thousand residents. Among the five most popular litigation districts, the Northern District of California ranked first, with 5.5 patents per thousand; the District of Massachusetts ranked ninth, with 2.3 patents per thousand; the District of Delaware ranked seventeenth, with 1.9

regression reflects a greater likelihood of a patentee win, but in assessing magnitude of the effects, note that the range is from 1 to 3 , not 0 to 1 .

19 We think excluding mixed verdicts is the preferable approach because mixed verdicts are rulings both for and against patentees.

We did not include other variables of possible interest in the multivariate regressions, such as technology category or the characteristics of individual patents, because the small number of trials would have prevented the results from having any possible predictive power.

20 Tegal Corp., 257 F.3d at 1339.

$21 \quad$ See 28 U.S.C. $\S 1498$ (2006).

22 We constructed this measure based on raw data collected by Michael Meehan. See Michael Meehan, Untapped Inventive Potential in U.S. Communities (Mar. 2009) (unpublished paper), http://works.bepr ess.com/michael_meehan/2/. Meehan collected data on patents by Metropolitan Statistical Measurement Area ("MSMA"). Id. We then converted MSMA data into judicial districts, which in some cases required estimation of residents on each side of a district boundary, and determined the population of each district. 
patents per thousand; the Central District of California ranked forty-third, with 1.2 patents per thousand; and the Eastern District of Texas ranked seventy-third, with 0.6 patents per thousand. ${ }^{23}$ Nonetheless, the patent sophistication of the jury pool had no statistically significant effect on trial outcomes. ${ }^{24}$

\section{TRIAL TIMES}

On average, patent trials last approximately eight court days, though the actual trial lengths range from one day to forty-four days. ${ }^{25}$ The length of a trial depends heavily on whether the trial involves a jury. Jury trials took an average of 8.60 days and a median of 8 days, compared with an average of 5.74 days and a median of 5 days for bench trials. ${ }^{26}$ We present the data in Table $1 .{ }^{27}$

Contrary to the conventional wisdom, however, the length of trial had no effect on outcome. The trial times were virtually identical for patentee wins and accused infringer wins. Patentee wins took 7.76 days on average, while accused infringer wins took 7.74 days. The median was 7 days for both sets of cases. This difference was not statistically significant even when no other variables were considered in the regression. This is not merely a failure to reject

23 We report the full results in Appendix C. See infra Appendix C pp. 201-03. The inclusion of district fixed effects in our data set for five of the sixty districts that had at least one patent trial creates some risk of multicollinearity with district-based patents-per-thousand measure.

24 This casts some doubt on the efficacy of proposals to allow district jury specialization. See, e.g., Jeanne C. Fromer, Patentography, 85 N.Y.U. L. REV. $1444,1481-82$ (2010) (proposing court specialization based on local industry clusters).

25 Trial events result in daily docket entries, so we can use Lex Machina to measure the number of days actually in trial, skipping days when the court is dark or hearing other matters. We did not attempt to determine the number of trial hours in any given day.

26 One possible explanation is that the docket reports for jury trials include the time the jury spends in deliberation. Judges instead write their opinions at some later time rather than devoting trial days to deliberation. We do not have a simple way to back out jury deliberation time, but we are skeptical that juries deliberate for an average of three days after a five-day presentation of evidence. So jury deliberation time is, at most, a partial explanation for this disparity.

$27 \quad$ See supra Table 1 p. 173. 
the null hypothesis out of statistical caution; our results suggest no real relationship between trial time and outcome.

Split decisions took longer: 9.42 days on average, with a median of 9 days. This is unsurprising; those cases are likely to be more complicated, as they tend to involve multiple patents or patent owners on both sides.

While bench trials are significantly shorter than jury trials, both bench and jury trials are approximately the same length in patentee wins and accused infringer wins. Patentee wins in bench trials took slightly longer than accused infringer wins, with a mean of 5.74 days for patentee wins compared to 5.40 days for accused infringer wins. By contrast, patentee wins in jury trials took slightly less time (8.32 days compared to 8.87 days for accused infringer wins), but the differences are not statistically significant even when only trial length and bench or jury are included in the regression. ${ }^{28}$ We present the results in Table $1 .{ }^{29}$

Trial length can also be affected by the characteristics of particular trials. Trials with multiple patents, multiple defendants, or both, can render a trial more complex and hence longer. Accordingly, we included these trials in our multivariate regression, but they didn't change the significance of any of the trial outcome results. ${ }^{30}$

\section{CHOICE OF FORUM}

A significant number of the 624 patent trials were held in just five districts: the Eastern District of Texas (77 trials), the District of Delaware (110 trials), the Northern District of California (33 trials), the Central District of California (25 trials), and the District of Massachusetts (28 trials). Together, those districts held more than $40 \%$ of the patent trials in the last ten years.

Different districts vary in the length of their trials, the percentage of bench trials, and the outcomes of those trials. In the Eastern District of Texas, the vast majority of trials are before juries (72 out of 77 trials). Both bench and jury

28 To avoid possible collinearity between the jury trial and trial length variables, we first ran these numbers including both sets and then ran those specific to jury trials. We found no significant difference in the results.

$29 \quad$ See supra Table 1 p. 173.

30 We ran the regressions using actual trial length. We also ran the regressions using quartiles to control for heteroskedasticity in trial lengths, but the results were similar. 
trials took less time than average: 6.18 days for jury trials and 3.6 days for bench trials. Patentees won one of the five bench trials in the Eastern District of Texas, accused infringers won three, and one case was a split decision. These percentages aren't particularly meaningful, however, because of the small number of cases. More significantly, patentees won $70.8 \%$ of jury trials in the Eastern District of Texas, accused infringers won $25.0 \%$, and $4.2 \%$ were split decisions. We report the results in Table 2.

Table 2: Trial Outcomes in the Eastern District of Texas

\begin{tabular}{|c|c|c|c|c|c|c|}
\hline Variable & $\begin{array}{l}\text { No. of } \\
\text { Variable }\end{array}$ & $\begin{array}{l}\text { Total } \\
\text { No. }\end{array}$ & $\begin{array}{l}\% \text { of } \\
\text { Total No. }\end{array}$ & $\begin{array}{l}\text { Mean Time } \\
\text { (Days) }\end{array}$ & $\begin{array}{l}\text { Median } \\
\text { Time }\end{array}$ & $\begin{array}{l}\text { Standard } \\
\text { Deviation }\end{array}$ \\
\hline $\begin{array}{l}\text { Total } \\
\text { Bench }\end{array}$ & 5 & 77 & $6.5 \%$ & 3.60 & 3 & 1.62 \\
\hline $\begin{array}{l}\text { Total } \\
\text { Jury }\end{array}$ & 72 & 77 & $93.5 \%$ & 6.18 & 6 & 2.12 \\
\hline $\begin{array}{l}\text { Bench } \\
\text { for C } \\
\text { Win } \\
\end{array}$ & 1 & 5 & $20.0 \%$ & 3.00 & 3 & 0.00 \\
\hline $\begin{array}{l}\text { Bench } \\
\text { For CD } \\
\text { Win }\end{array}$ & 3 & 5 & $60.0 \%$ & 3.00 & 2 & 1.41 \\
\hline $\begin{array}{l}\text { Bench } \\
\text { For C; } \\
\text { CD Win }\end{array}$ & 1 & 5 & $20.0 \%$ & 6.00 & 6 & 0.00 \\
\hline $\begin{array}{l}\text { Jury } \\
\text { Trial for } \\
\text { C Win }\end{array}$ & 51 & 72 & $70.8 \%$ & 6.14 & 6 & 1.78 \\
\hline $\begin{array}{l}\text { Jury } \\
\text { Trial for } \\
\text { CD Win }\end{array}$ & 18 & 72 & $25.0 \%$ & 6.11 & 5 & 2.86 \\
\hline $\begin{array}{l}\text { Jury } \\
\text { Trial for } \\
\text { C; CD } \\
\text { Win }\end{array}$ & 3 & 72 & $4.2 \%$ & 7.33 & 7 & 2.05 \\
\hline
\end{tabular}


In the Northern District of California, twenty-seven out of thirty-three trials were before juries. The bench trials were somewhat shorter than average at 5.5 days, but jury trials took much longer, averaging 12.7 days. Patentees won two of six bench trials, accused infringers won three, and one case was a split decision. Again, because of the small number of cases, the bench trial percentages don't seem particularly meaningful. Juries were far less favorable to patentees in the Northern District of California than in the Eastern District of Texas. In the Northern District of California, patentees won only $44.4 \%$ of jury trials, accused infringers won $48.1 \%$, and $7.4 \%$ were split decisions. We report the results in Table 3.

Table 3: Trial Outcomes in the Northern District of California

\begin{tabular}{|l|l|l|l|l|l|l|}
\hline Variable & $\begin{array}{l}\text { No. of } \\
\text { Variable }\end{array}$ & $\begin{array}{l}\text { Total } \\
\text { No. }\end{array}$ & $\begin{array}{l}\% \text { of } \\
\text { Total No. }\end{array}$ & $\begin{array}{l}\text { Mean Time } \\
\text { (Days) }\end{array}$ & $\begin{array}{l}\text { Median } \\
\text { Time }\end{array}$ & $\begin{array}{l}\text { Standard } \\
\text { Deviation }\end{array}$ \\
\hline $\begin{array}{l}\text { Total } \\
\text { Bench }\end{array}$ & 6 & 33 & $18.2 \%$ & 5.50 & 4.5 & 3.15 \\
\hline $\begin{array}{l}\text { Total } \\
\text { Jury }\end{array}$ & 27 & 33 & $81.8 \%$ & 12.67 & 12 & 4.28 \\
\hline $\begin{array}{l}\text { Bench } \\
\text { for C } \\
\text { Win }\end{array}$ & 2 & 6 & $33.3 \%$ & 7.00 & 7 & 5.00 \\
\hline $\begin{array}{l}\text { Bench } \\
\text { For CD } \\
\text { Win }\end{array}$ & 3 & 6 & $50.0 \%$ & 4.33 & 4 & 0.47 \\
\hline $\begin{array}{l}\text { Bench } \\
\text { For C; } \\
\text { CD Win }\end{array}$ & 1 & 6 & $16.7 \%$ & 6.00 & 6 & 0.00 \\
\hline $\begin{array}{l}\text { Jury } \\
\text { Trial for } \\
\text { C Win }\end{array}$ & 12 & 27 & $44.4 \%$ & 13.75 & 12 & 5.46 \\
\hline $\begin{array}{l}\text { Jury } \\
\text { Trial for } \\
\text { CD Win }\end{array}$ & 13 & 27 & $48.1 \%$ & 11.46 & 11 & 2.65 \\
\hline $\begin{array}{l}\text { Jury } \\
\text { Trial for } \\
\text { C; CD } \\
\text { Win }\end{array}$ & 2 & 27 & $7.4 \%$ & 14.00 & 14 & 2.00 \\
\hline
\end{tabular}


In the Central District of California, twenty-one out of twenty-five trials were before juries. The bench trials were substantially shorter than average, at 3.75 days, and jury trials took slightly less than average at 8.24 days. Patentees won two of four bench trials in the Northern District of California and accused infringers won two. These numbers too are too small to draw any meaningful conclusions about bench trials. Juries were generally favorable to patentees in the Central District of California, though not quite as favorable as in the Eastern District of Texas. In the Central District of California, patentees won 66.7\% of jury trials, accused infringers won $28.6 \%$, and $4.8 \%$ were split decisions. We report the results in Table 4.

Table 4: Trial Outcomes in the Central District of California

\begin{tabular}{|l|l|l|l|l|l|l|}
\hline Variable & $\begin{array}{l}\text { No. of } \\
\text { Variable }\end{array}$ & $\begin{array}{l}\text { Total } \\
\text { No. }\end{array}$ & $\begin{array}{l}\text { \% of } \\
\text { Total No. }\end{array}$ & $\begin{array}{l}\text { Mean Time } \\
\text { (Days) }\end{array}$ & $\begin{array}{l}\text { Median } \\
\text { Time }\end{array}$ & $\begin{array}{l}\text { Standard } \\
\text { Deviation }\end{array}$ \\
\hline $\begin{array}{l}\text { Total } \\
\text { Bench }\end{array}$ & 4 & 25 & $16.0 \%$ & 3.75 & 4 & 1.30 \\
\hline $\begin{array}{l}\text { Total } \\
\text { Jury }\end{array}$ & 21 & 25 & $84.0 \%$ & 8.24 & 7 & 5.00 \\
\hline $\begin{array}{l}\text { Bench } \\
\text { for C } \\
\text { Win }\end{array}$ & 2 & 4 & $50.0 \%$ & 2.50 & 2.5 & 0.50 \\
\hline $\begin{array}{l}\text { Bench } \\
\text { For CD } \\
\text { Win }\end{array}$ & 2 & 4 & $50.0 \%$ & 5.00 & 5 & 0.00 \\
\hline $\begin{array}{l}\text { Bench } \\
\text { For C; } \\
\text { CD Win }\end{array}$ & 0 & 4 & $0.0 \%$ & 0.00 & 0 & 0.00 \\
\hline & & & & & & \\
\hline $\begin{array}{l}\text { Jury } \\
\text { Trial for } \\
\text { C Win }\end{array}$ & 14 & 21 & $66.7 \%$ & 7.00 & 6.5 & 3.14 \\
\hline $\begin{array}{l}\text { Jury } \\
\text { Trial for } \\
\text { CD Win }\end{array}$ & 6 & 21 & $28.6 \%$ & 8.50 & 7.5 & 4.43 \\
\hline $\begin{array}{l}\text { Jury } \\
\text { Trial for } \\
\text { C; CD } \\
\text { Win }\end{array}$ & 1 & & & & & \\
\hline
\end{tabular}


In the District of Delaware, 70 out of 110 trials (or 63.6\%) were before juries, a far lower percentage than in the other districts we investigated. This is likely an artifact of the prevalence of generic pharmaceutical patent cases in Delaware, which are not normally tried to juries. Bench trials in Delaware were slightly shorter than average, at 5.08 days, as were jury trials, at 7.96 days. Patentees won $57.5 \%$ of bench trials in the District of Delaware, accused infringers won $37.5 \%$, and $5 \%$ were split decisions. Juries were somewhat less favorable to patentees in the District of Delaware than in the Eastern District of Texas. In Delaware, patentees won only $55.7 \%$ of jury trials, accused infringers won $22.9 \%$, and $21.4 \%$ were split decisions. Delaware was the only district of the five we broke out in which judges ruled for patentees at a higher rate than juries did, though the large number of split jury decisions may be a partial explanation. We report the results in Table 5. 
Table 5: Trial Outcomes in the District of Delaware

\begin{tabular}{|l|l|l|l|l|l|l|}
\hline Variable & $\begin{array}{l}\text { No. of } \\
\text { Variable }\end{array}$ & $\begin{array}{l}\text { Total } \\
\text { No. }\end{array}$ & $\begin{array}{l}\text { \% of } \\
\text { Total No. }\end{array}$ & $\begin{array}{l}\text { Mean Time } \\
\text { (Days) }\end{array}$ & $\begin{array}{l}\text { Median } \\
\text { Time }\end{array}$ & $\begin{array}{l}\text { Standard } \\
\text { Deviation }\end{array}$ \\
\hline $\begin{array}{l}\text { Total } \\
\text { Bench }\end{array}$ & 40 & 110 & $36.4 \%$ & 5.08 & 5 & 1.84 \\
\hline $\begin{array}{l}\text { Total } \\
\text { Jury }\end{array}$ & 70 & 110 & $63.6 \%$ & 7.96 & 8 & 2.86 \\
\hline $\begin{array}{l}\text { Bench } \\
\text { for C } \\
\text { Win }\end{array}$ & 23 & 40 & $57.5 \%$ & 5.09 & 5 & 1.69 \\
\hline $\begin{array}{l}\text { Bench } \\
\text { For CD } \\
\text { Win }\end{array}$ & 15 & 40 & $37.5 \%$ & 4.60 & 5 & 1.58 \\
\hline $\begin{array}{l}\text { Bench } \\
\text { For C; } \\
\text { CD Win }\end{array}$ & 2 & 40 & $5.0 \%$ & 8.50 & 8.5 & 1.50 \\
\hline $\begin{array}{l}\text { Jury } \\
\text { Trial for } \\
\text { C Win }\end{array}$ & 39 & 70 & $55.7 \%$ & 7.82 & 8 & 2.85 \\
\hline $\begin{array}{l}\text { Jury } \\
\text { Trial for } \\
\text { CD Win }\end{array}$ & 16 & 70 & $22.9 \%$ & 8.19 & 8 & \\
\hline $\begin{array}{l}\text { Jury } \\
\text { Trial for } \\
\text { C; CD } \\
\text { Win }\end{array}$ & 15 & 70 & $21.4 \%$ & 8.07 & & \\
\hline
\end{tabular}

In the District of Massachusetts, twenty-three out of twenty-eight trials were before juries. Both bench and jury trials were substantially longer than average, at a mean of 7.80 days and 11.04 days, respectively. Patentees won one out of five bench trials in the District of Massachusetts, accused infringers won three, and the final case was a split decision. As in other districts, the small number of cases renders these percentages less meaningful. Juries in the District of Massachusetts were slightly less favorable to patentees than in the country as a whole. Patentees won $56.5 \%$ of jury trials, accused infringers won $39.1 \%$, and $4.3 \%$ were split decisions. We report the results in Table 6 . 
Table 6: Trial Outcomes in the District of Massachusetts

\begin{tabular}{|l|l|l|l|l|l|l|}
\hline Variable & $\begin{array}{l}\text { No. of } \\
\text { Variable }\end{array}$ & $\begin{array}{l}\text { Total } \\
\text { No. }\end{array}$ & $\begin{array}{l}\% \text { of } \\
\text { Total No. }\end{array}$ & $\begin{array}{l}\text { Mean Time } \\
\text { (Days) }\end{array}$ & $\begin{array}{l}\text { Median } \\
\text { Time }\end{array}$ & $\begin{array}{l}\text { Standard } \\
\text { Deviation }\end{array}$ \\
\hline $\begin{array}{l}\text { Total } \\
\text { Bench }\end{array}$ & 5 & 28 & $17.9 \%$ & 7.80 & 5 & 5.64 \\
\hline $\begin{array}{l}\text { Total } \\
\text { Jury }\end{array}$ & 23 & 28 & $82.1 \%$ & 11.04 & 9 & 8.38 \\
\hline $\begin{array}{l}\text { Bench } \\
\text { for C } \\
\text { Win }\end{array}$ & 1 & 5 & $20.0 \%$ & 3.00 & 3 & 0.00 \\
\hline $\begin{array}{l}\text { Bench } \\
\text { For CD } \\
\text { Win }\end{array}$ & 3 & 5 & $60.0 \%$ & 7.67 & 5 & 6.02 \\
\hline $\begin{array}{l}\text { Bench } \\
\text { For C; } \\
\text { CD Win }\end{array}$ & 1 & 5 & $20.0 \%$ & 13.00 & 13 & 0.00 \\
\hline $\begin{array}{l}\text { Jury } \\
\text { Trial for } \\
\text { C Win }\end{array}$ & 13 & 23 & $56.5 \%$ & 12.85 & 9 & 9.92 \\
\hline $\begin{array}{l}\text { Jury } \\
\text { Trial for } \\
\text { CD Win }\end{array}$ & 9 & 23 & $39.1 \%$ & 8.44 & 6 & \\
\hline $\begin{array}{l}\text { Jury } \\
\text { Trial for } \\
\text { C; CD } \\
\text { Win }\end{array}$ & 1 & 23 & $4.3 \%$ & 11.00 & 11 & 0.00 \\
\hline
\end{tabular}

The results show some substantial differences in trial outcomes by district, though the magnitude of those differences is smaller than expected. In particular, the conventional wisdom that juries in the Eastern District of Texas always vote for patentees is not true. While juries in that district do find for patentees more often than the national average, the difference between $70.8 \%$ in the Eastern District of Texas and $62.9 \%$ overall is not as large as expected. Indeed, as the multiple regression analysis in the appendices shows, it is not statistically significant once we factor in the number of patents, the number of defendants, whether a judge or a jury decided the issue, whether there were nonpatent issues in the case, and whether the case resulted in a split decision. Similarly, although the Northern District of California seems to have a much 
lower jury win rate at $44.4 \%$ compared to $62.9 \%$ overall, the effects are not statistically significant in the overall regression analysis, in part because of the small number of jury trials in that district.

Figure 3: Jury Trial Favorable to Patentee Rate By District

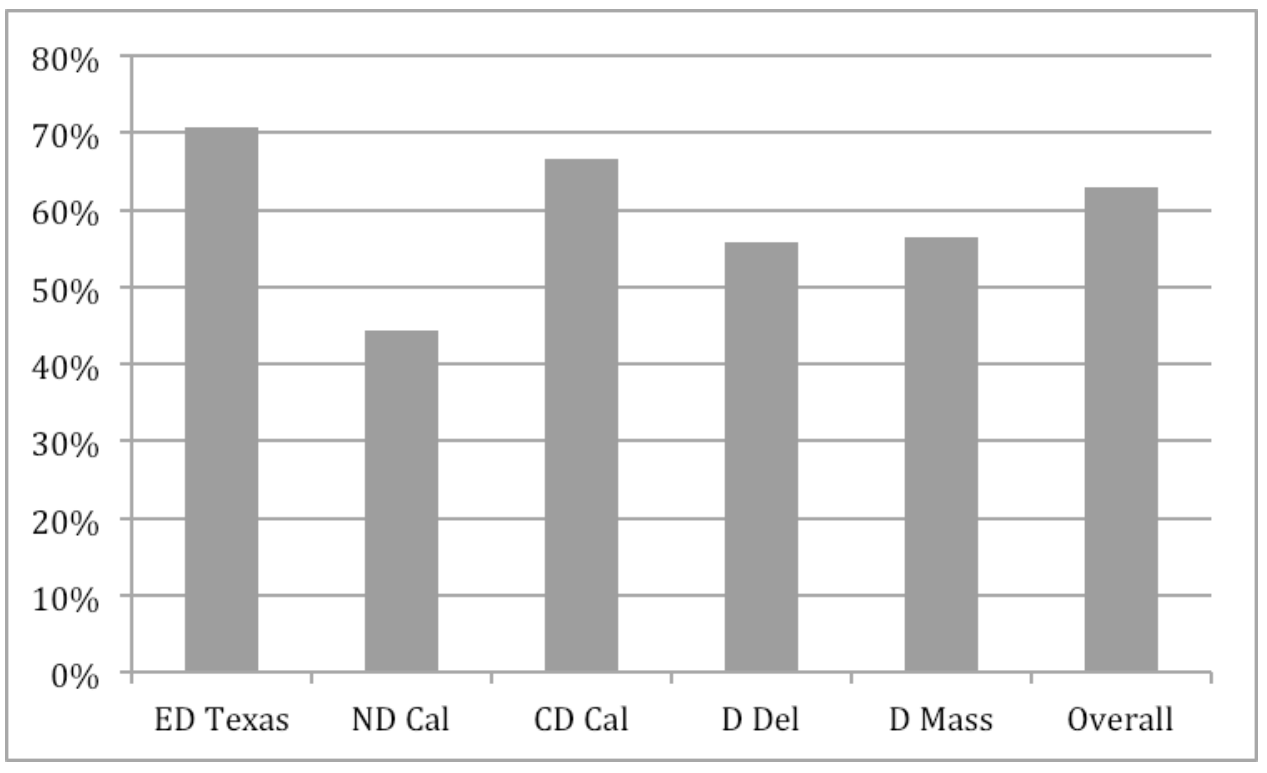

The evidence shows some differences in line with the conventional wisdom that patentees win more before juries in the Eastern District of Texas and the District of Delaware than in the Northern District of California. But it does not support the conclusion that the district in which a case is litigated significantly affects the likelihood that the jury will find for the patentee. ${ }^{31}$

\section{Predicting the Length of Patent Trials}

So far, we have been trying, and failing, to predict the outcome of patent trials based on their length or location. In this section, we reverse the process to look at the factors that best predict the length of a patent trial. Here, when holding all other variables constant, we find abundant and strongly significant evidence of relationships. Trial before a jury is a significant predictor of a long trial, adding 3.04 days to the length of the trial $(\mathrm{p}<0.001)$. Certain trial complexities also correlate with greater length. For example, adding an

31 For discussion of technology-specific clustering of cases and the effect of the jury pool in particular districts, see Fromer, supra note 24, at 1450. 
additional patent to the case adds 0.83 days $(\mathrm{p}<0.001)$, while adding an additional defendant to the case adds 0.38 days $(\mathrm{p}=0.012)$. Adding non-patent issues to the case, by contrast, does not have a statistically significant effect. We report these results in Appendix B. ${ }^{32}$

This evidence suggests that trial lengths will likely decrease now that joining multiple defendants in a single case is difficult under the America Invents Act of 2011. ${ }^{33}$ The new joinder provisions limit the defendants that can be joined in the same suit. ${ }^{34}$ The number of defendants per case has dropped significantly, simplifying each trial and predicting shorter overall lengths. ${ }^{35}$

The district of choice also affects the length of trials. Conducting a trial in the Eastern District of Texas, the Central District of California, or the District of Delaware is significantly correlated with a shorter trial $(p<0.001, p<0.001$, and $\mathrm{p}=0.013$, respectively). ${ }^{36}$ Conducting a trial in the Northern District of California is not significantly correlated with a longer trial $(\mathrm{p}=0.437)$. The Northern District of California and the District of Massachusetts do, however, take longer on average than districts other than the five we broke out for analysis. Those remaining districts were associated with trials that were 2.07 days shorter, all else remaining equal $(\mathrm{p}=0.013)$.

Curiously, the number of patents per thousand people in the jury pool correlated significantly with a longer trial $(p<0.001) \cdot{ }^{37}$ It is not clear what explains

32 See infra Appendix B pp. 196-200.

33 See James C. Pistorino \& Susan J. Crane, 2011 Trends in Patent Case Filings: Eastern District of Texas Continues to Lead Until America Invents Act Is Signed, 83 PAT. TRADEMARK \& COPYRIGHT J. (BNA) 710, 713-14 (Mar. 2012) (documenting a significant drop in the number of defendants per case after the AIA took effect in September 2011).

3435 U.S.C.A. § 299(b)-(c) (West 2013).

35 See Pistorino \& Crane, supra note 33, at 713-14.

36 The differences between the five broken out districts were substantial. Holding other variables constant, trials took 4.82 fewer days in the Eastern District of Texas, 3.26 fewer days in the District of Delaware, and 2.84 fewer days in the Central District of California than in the District of Massachusetts.

37 The significance of the effect disappeared when we added district dummy variables, however, as did the significance of the individual district effects, though that is likely the result of collinearity. 
this result; it might be a function of longer trial times in the Northern District of California and the District of Massachusetts, both of which rank high on the patent-intensity list, and shorter trial times in the less patent-intense Eastern District of Texas. Alternatively, an unobserved variable may explain both results. Perhaps trials conducted in higher-tech districts tend to involve more complex technology than trials in other districts, resulting in longer trials. To test the strength of this relationship, we ran a version of the regression that omitted the Northern District of California and the Eastern District of Texas. The significance of the patents-per-thousand measure disappeared $(\mathrm{p}=0.363)$, while the other predictors remained significant. That suggests the effect is an artifact of something particular about one or both of those districts. While certain unknowns do remain, juries, trial complexity, and the district of choice all have significant effects on the overall length of a trial.

\section{CONCLUSION}

Short trials don't benefit patentees, as the conventional wisdom suggests. In fact, trial length seems to have no effect on outcomes at all. There are some predictors of success-juries rule for patentees more than judges, and juries in some districts appear to be more likely to find for patentees than are others. But the inter-district results are much more modest than most people suspect. We think this is an encouraging sign; some of the anxiety around the Eastern District of Texas and District of Delaware juries seems unwarranted.

In the absence of any evidence that trial length affects outcomes, predictors of trial length may be significant for policy purposes. If the length of a trial doesn't skew outcomes, one might reasonably argue that long trials are a waste of party and judicial resources. Far from a rush to judgment, a short patent trial may produce the same outcome more quickly and cheaply. 


\section{APPENDIX A:}

\section{REGRESSIONS WITH OUTCOME AS DEPENDENT VARIABLE FROM THE DATA SET USING TWO OUTCOMES AND SPLITTING C/CD INTO BOTH C AND CD: $\mathrm{C}=1 \mathrm{CD}=3^{38}$}

Jury trial $=1$; bench trial $=0$

Descriptive stats:

. summarize

\begin{tabular}{|c|c|c|c|c|c|}
\hline Variable & Obs & Mean & Std.Dev. & Min & $\operatorname{Max}$ \\
\hline Caseid & 669 & $7.18 \mathrm{E}+07$ & $2.91 \mathrm{E}+08$ & 11 & $2.00 \mathrm{E}+09$ \\
\hline districtec $\sim \mathrm{r}$ & 0 & & & & \\
\hline district_c & 669 & 4.366218 & 2.002721 & 1 & 6 \\
\hline edtx & 669 & 0.1210762 & 0.3264599 & 0 & 1 \\
\hline ddel & 669 & 0.1898356 & 0.3924644 & 0 & 1 \\
\hline Cdcal & 669 & 0.038864 & 0.1934153 & 0 & 1 \\
\hline Ndcal & 669 & 0.0538117 & 0.2258145 & 0 & 1 \\
\hline Dmass & 669 & 0.044843 & 0.2071141 & 0 & 1 \\
\hline Dother & 669 & 0.5515695 & 0.4977056 & 0 & 1 \\
\hline trial_len $\mathrm{h}$ & 669 & 7.977578 & 4.650778 & 1 & 44 \\
\hline trial_len _ & 669 & 2.657698 & 1.105656 & 1 & 4 \\
\hline jury_trial & 669 & 0.7488789 & 0.4339825 & 0 & 1 \\
\hline patents 1 & 669 & 1.982063 & 1.615691 & 1 & 14 \\
\hline patents _ & 669 & 2.168909 & 1.297114 & 1 & 4 \\
\hline patents_1 & 669 & 0.4663677 & 0.4992409 & 0 & 1 \\
\hline plaintif & 669 & 1.313901 & 0.6856972 & 1 & 8 \\
\hline defenda 1 & 669 & 1.606876 & 1.077539 & 1 & 11 \\
\hline defenda _ & 669 & 1.859492 & 1.186748 & 1 & 4 \\
\hline defenda 1 & 669 & 0.3587444 & 0.4799909 & 0 & 1 \\
\hline prevailing & 669 & 1.747384 & 0.9682906 & 1 & 3 \\
\hline additional & 669 & 0.0523169 & 0.2228319 & 0 & 1 \\
\hline
\end{tabular}

38 We ran separate regressions treating split decisions as a half-decision for each party, as a full decision for each party, and excluding split decisions entirely. The results were not meaningfully different. We have chosen to report here the regression that treats split decisions as both patentee and accused infringer wins; the number of observations is larger than 624 in this regression because each split decision was processed twice. 
.regress prevailing_party_in_trial trial_length

\begin{tabular}{|c|c|c|c|}
\hline Source & SS & Df & MS \\
\hline Model & 0.0674188 & 1 & 0.067418808 \\
\hline Residual & 626.2405 & 667 & 0.93889131 \\
\hline Total & 626.30792 & 668 & 0.93758671 \\
\hline
\end{tabular}

\begin{tabular}{|c|c|}
\hline Number of obs & 669 \\
\hline $\mathrm{F}(1,667)$ & 0.07 \\
\hline Prob $>$ F & 0.7888 \\
\hline R-squared & 0.0001 \\
\hline Adj R-squared & -0.0014 \\
\hline Root MSE & 0.96896 \\
\hline
\end{tabular}

\begin{tabular}{|c|c|c|c|c|c|}
\hline prevailing & Coef. & Std.Err. & $t$ & $P>|t|$ & [95\% Conf. Interval] \\
\hline trial_len $\sim h$ & 0.0021601 & 0.0080611 & 0.27 & 0.789 & $\begin{array}{lll}-0.0136681 & 0.0179883\end{array}$ \\
\hline _cons & 1.730152 & 0.0744241 & 23.25 & 0 & 1.5840181 .876285 \\
\hline
\end{tabular}

.regress prevailing_party_in_trial trial_length jury_trial

\begin{tabular}{|c|c|c|c|}
\hline Source & SS & $d f$ & $M S$ \\
\hline Model & 7.34523299 & 2 & 3.67261649 \\
\hline Residual & 618.962689 & 666 & 0.929373407 \\
\hline Total & 626.307922 & 668 & 0.93758671 \\
\hline
\end{tabular}

\begin{tabular}{|c|c|}
\hline Number of obs & 669 \\
\hline $\mathrm{F}(2,666)$ & 3.95 \\
\hline Prob>F & 0.0197 \\
\hline R-squared & 0.0117 \\
\hline AdjR-squared & 0.0088 \\
\hline RootMSE & 0.96404 \\
\hline
\end{tabular}

\begin{tabular}{|c|c|c|c|c|c|}
\hline prevailing & Coef. & Std.Err. & $t$ & $P>|t|$ & [95\% Conf. Interval] \\
\hline trial_len h & 0.0082529 & 0.0083104 & 0.99 & 0.321 & -0.00806490 .0245706 \\
\hline jury_trial & -0.249219 & 0.0890586 & -2.8 & 0.005 & $-0.4240884-0.0743496$ \\
\hline _cons & 1.868181 & 0.0889704 & 21 & 0 & 1.6934852 .042877 \\
\hline
\end{tabular}


.regress prevailing_party_in_trial trial_length jury_trial_patents_in_trial

\begin{tabular}{|c|c|c|c|}
\hline Source & SS & $d f$ & $M S$ \\
\hline Model & 8.32555858 & 3 & 2.77518619 \\
\hline Residual & 617.982364 & 665 & 0.929296788 \\
\hline Total & 626.307922 & 668 & 0.93758671 \\
\hline
\end{tabular}

\begin{tabular}{|c|c|}
\hline Number of obs & 669 \\
\hline $\mathrm{F}(3,665)$ & 2.99 \\
\hline Prob $>\mathrm{F}$ & 0.0306 \\
\hline R-squared & 0.0133 \\
\hline AdjR-squared & 0.0088 \\
\hline RootMSE & 0.964 \\
\hline
\end{tabular}

\begin{tabular}{|c|c|c|c|c|c|}
\hline prevailing & Coef. & Std.Err. & $T$ & $P>|t|$ & [95\% Conf. Interval] \\
\hline trial_len $\mathrm{h}$ & 0.0058215 & 0.0086407 & 0.67 & 0.501 & $\begin{array}{lll}-0.0111448 & 0.0227878\end{array}$ \\
\hline jury_trial & -0.2404299 & 0.0894651 & -2.69 & 0.007 & $-0.416098-0.0647618$ \\
\hline __patents 1 & 0.0246593 & 0.0240089 & 1.03 & 0.305 & $\begin{array}{lll}-0.0224831 & 0.0718018 \\
\end{array}$ \\
\hline _cons & 1.832119 & 0.0956443 & 19.16 & 0 & $1.644318 \quad 2.01992$ \\
\hline
\end{tabular}

.regress prevailing_party_in_trial trial_length jury_trial_patents_in_trial edtx ddelcdcal ndcal dmass dother_plaintiffs_in_trial__defendants_in_trial additional_issues

\begin{tabular}{|c|c|c|c|}
\hline Source & SS & $d f$ & $M S$ \\
\hline Model & 14.5490892 & 11 & 1.32264447 \\
\hline Residual & 611.758833 & 657 & 0.931139776 \\
\hline Total & 626.307922 & 668 & 0.93758671 \\
\hline
\end{tabular}

\begin{tabular}{|c|c|}
\hline Number of obs & 669 \\
\hline $\mathrm{F}(11,657)$ & 1.42 \\
\hline Prob>F & 0.1588 \\
\hline R-squared & 0.0232 \\
\hline AdjR-squared & 0.0069 \\
\hline RootMSE & 0.96496 \\
\hline
\end{tabular}




\begin{tabular}{|c|c|c|c|c|c|}
\hline prevailing & Coef. & Std.Err. & $t$ & $P>|t|$ & [95\% Conf. Interval] \\
\hline trial_len h & -0.0003208 & 0.0091685 & -0.03 & 0.972 & -0.01832390 .0176823 \\
\hline jury_trial & -0.217106 & 0.0924617 & -2.35 & 0.019 & $-0.398662 \quad-0.03555$ \\
\hline __patents 1 & 0.0274261 & 0.0244632 & 1.12 & 0.263 & -0.02060950 .0754617 \\
\hline edtx & -0.0589709 & 0.2191022 & -0.27 & 0.788 & -0.48919580 .3712541 \\
\hline ddel & -0.0023012 & 0.2101053 & -0.01 & 0.991 & -0.414860 .4102575 \\
\hline cdcal & (dropped) & & & & \\
\hline ndcal & 0.3551943 & 0.2506972 & 1.42 & 0.157 & -0.137070 .8474587 \\
\hline dmass & 0.2102005 & 0.2606164 & 0.81 & 0.42 & -0.30154090 .7219419 \\
\hline dother & 0.0032854 & 0.1966267 & 0.02 & 0.987 & -0.38280720 .3893779 \\
\hline -_plaintif & 0.053418 & 0.0558458 & 0.96 & 0.339 & -0.05623980 .1630758 \\
\hline defenda 1 & -0.0084891 & 0.035005 & -0.24 & 0.808 & -0.07722420 .060246 \\
\hline additional & 0.0479934 & 0.1691918 & 0.28 & 0.777 & -0.28422860 .3802153 \\
\hline _cons & 1.776339 & 0.2252098 & 7.89 & 0 & 1.3341212 .218556 \\
\hline
\end{tabular}

_regress prevailing_party_in_trial jury_trial edtx ddel cdcal ndcal dmass dother __plaintiffs_in_trial additional_issues trial_length_quartile__patents_quartile_ __defendants_quartile_

\begin{tabular}{|c|c|c|c|}
\hline Source & SS & $d f$ & $M S$ \\
\hline Model & 14.8323317 & 11 & 1.34839379 \\
\hline Residual & 611.475591 & 657 & 0.930708662 \\
\hline Total & 626.307922 & 668 & 0.93758671 \\
\hline
\end{tabular}

\begin{tabular}{|c|c|}
\hline Number of obs & 669 \\
\hline $\mathrm{F}(11,657)$ & 1.45 \\
\hline Prob>F & 0.1466 \\
\hline R-squared & 0.0237 \\
\hline AdjR-squared & 0.0073 \\
\hline RootMSE & 0.96473 \\
\hline
\end{tabular}




\begin{tabular}{|c|c|c|c|c|c|}
\hline prevailing & Coef. & Std. Err. & $t$ & $P>|t|$ & [95\% Conf. Interval] \\
\hline jury_trial & -0.2370499 & 0.0938834 & -2.52 & 0.012 & $-0.4213977-0.0527022$ \\
\hline edtx & -0.0591904 & 0.2184353 & -0.27 & 0.786 & $-0.4881059 \quad 0.369725$ \\
\hline ddel & -0.0086152 & 0.2101201 & -0.04 & 0.967 & -0.42120320 .4039727 \\
\hline cdcal & (dropped) & & & & \\
\hline ndcal & 0.3351314 & 0.2509773 & 1.34 & 0.182 & -0.1576830 .8279457 \\
\hline dmass & 0.2123572 & 0.2603434 & 0.82 & 0.415 & $-0.2988482 \quad 0.7235626$ \\
\hline dother & 0.0005423 & 0.1968305 & 0 & 0.998 & $-0.3859504 \quad 0.3870349$ \\
\hline _plaintif $\sim$ & 0.0572742 & 0.0554537 & 1.03 & 0.302 & -0.05161380 .1661621 \\
\hline additional & 0.0491457 & 0.1696762 & 0.29 & 0.772 & -0.28402730 .3823188 \\
\hline
\end{tabular}




\section{REGRESSIONS OMITTING DiSTRICT DUMMIES \\ BUT INCLUDING PATENT INTENSITY}

.regress prevailing_party_in_trial trial_length jury_trial__patents_in_trial _defendants_in_trial additional_issues patents_per_thousand_people

\begin{tabular}{|c|c|c|c|}
\hline Source & SS & $d f$ & $M S$ \\
\hline Model & 10.7812888 & 6 & 1.79688146 \\
\hline Residual & 615.526633 & 662 & 0.92979854 \\
\hline Total & 626.307922 & 668 & 0.93758671 \\
\hline
\end{tabular}

\begin{tabular}{|c|c|}
\hline Number of obs & 669 \\
\hline $\mathrm{F}(6,662)$ & 1.93 \\
\hline Prob>F & 0.0733 \\
\hline R-squared & 0.0172 \\
\hline AdjR-squared & 0.0083 \\
\hline RootMSE & 0.96426 \\
\hline
\end{tabular}

\begin{tabular}{|c|c|c|c|c|c|}
\hline prevailing & Coef. & Std. Err. & $t$ & $P>|t|$ & [95\% Conf. Interval] \\
\hline trial_len h h & 0.0028521 & 0.0089021 & 0.32 & 0.749 & -0.01462760 .0203318 \\
\hline jury_trial & -0.2278377 & 0.0902234 & -2.53 & 0.012 & $-0.4049963-0.0506791$ \\
\hline __patents 1 & 0.0275462 & 0.0241051 & 1.14 & 0.254 & $-0.0197855 \quad 0.074878$ \\
\hline __defenda 1 & -0.0069157 & 0.0348787 & -0.2 & 0.843 & -0.07540190 .0615704 \\
\hline additional & 0.0334596 & 0.168087 & 0.2 & 0.842 & -0.29658830 .3635074 \\
\hline patents_pe & 0.0557953 & 0.0347711 & 1.6 & 0.109 & $-0.0124796 \quad 0.1240702$ \\
\hline _cons & 1.754362 & 0.1230094 & 14.26 & 0.000 & 1.5128261 .995898 \\
\hline
\end{tabular}

.regress prevailing_party_in_trial trial_length jury_trial__patents_in_trial _plaintiffs_in_trial__defendants_in_trial additional_issues patents_per_thousand_people

\begin{tabular}{|c|c|c|c|}
\hline Source & SS & $d f$ & $M S$ \\
\hline Model & 11.6887109 & 7 & 1.66981585 \\
\hline Residual & 614.619211 & 661 & 0.929832392 \\
\hline Total & 626.307922 & 668 & 0.93758671 \\
\hline
\end{tabular}




\begin{tabular}{|c|c|}
\hline Number of obs & 669 \\
\hline $\mathrm{F}(7,661)$ & 1.8 \\
\hline Prob $>\mathrm{F}$ & 0.0853 \\
\hline R-squared & 0.0187 \\
\hline Adj R-squared & 0.0083 \\
\hline RootMSE & 0.96428 \\
\hline
\end{tabular}

\begin{tabular}{|c|c|c|c|c|c|}
\hline prevailing & Coef. & Std. Err. & $t$ & $P>|t|$ & [95\% Conf. Interval] \\
\hline trial_len h & 0.0020016 & 0.0089438 & 0.22 & 0.823 & $\begin{array}{lll}-0.01556 & 0.0195633\end{array}$ \\
\hline jury_trial & -0.2160602 & 0.0910093 & -2.37 & 0.018 & $\begin{array}{lll}-0.3947625 & -0.037358\end{array}$ \\
\hline __patents 1 & 0.0259666 & 0.0241586 & 1.07 & 0.283 & $-0.0214701 \quad 0.0734034$ \\
\hline __plaintif $\sim$ & 0.0547899 & 0.0554623 & 0.99 & 0.324 & $\begin{array}{lll}-0.0541136 & 0.1636934\end{array}$ \\
\hline __defenda 1 & -0.0088168 & 0.0349324 & -0.25 & 0.801 & -0.07740850 .059775 \\
\hline additional & 0.0397401 & 0.1682102 & 0.24 & 0.813 & $\begin{array}{lll}-0.2905507 & 0.3700308\end{array}$ \\
\hline patents_pe & 0.0576487 & 0.0348223 & 1.66 & 0.098 & $\begin{array}{lll}-0.0107269 & 0.1260244\end{array}$ \\
\hline _cons & 1.683018 & 0.1426448 & 11.8 & 0 & $1.402927 \quad 1.96311$ \\
\hline
\end{tabular}

.regress prevailing_party_in_trial jury_trial__plaintiffs_in_trial additional_issues patents_per_thousand_people trial_length_quartile__patents_quartile_ _defendants_quartile_

\begin{tabular}{|c|c|c|c|}
\hline Source & SS & $d f$ & $M S$ \\
\hline Model & 11.935029 & 7 & 1.70500415 \\
\hline Residual & 614.372893 & 661 & 0.929459748 \\
\hline Total & 626.307922 & 668 & 0.93758671 \\
\hline
\end{tabular}

\begin{tabular}{|c|c|}
\hline Number of obs & 669 \\
\hline $\mathrm{F}(7,661)$ & 1.83 \\
\hline Prob>F & 0.078 \\
\hline R-squared & 0.0191 \\
\hline Adj R-squared & 0.0087 \\
\hline Root MSE & 0.96408 \\
\hline
\end{tabular}




\begin{tabular}{|c|c|c|c|c|c|}
\hline prevailing & Coef. & Std. Err. & $t$ & $P>|t|$ & [95\% Conf. Interval] \\
\hline jury_trial & -0.2317575 & 0.0924892 & -2.51 & 0.012 & $-0.4133656-0.0501495$ \\
\hline _plaintif & 0.0592926 & 0.0550335 & 1.08 & 0.282 & $-0.0487689 \quad 0.167354$ \\
\hline additional & 0.0410023 & 0.1688328 & 0.24 & 0.808 & -0.2905110 .3725156 \\
\hline patents_pe & 0.055087 & 0.0347801 & 1.58 & 0.114 & -0.01320580 .1233797 \\
\hline trial_len _ & 0.0168431 & 0.0378376 & 0.45 & 0.656 & -0.05745330 .0911395 \\
\hline __patents _ & 0.0302969 & 0.0299484 & 1.01 & 0.312 & -0.02850850 .0891024 \\
\hline __defenda _ & 0.0118745 & 0.0316896 & 0.37 & 0.708 & $-0.0503498 \quad 0.0740989$ \\
\hline _cons & 1.613896 & 0.1542296 & 10.46 & 0 & 1.3110571 .916735 \\
\hline
\end{tabular}




\section{APPENDIX B:}

\section{REGRESSIONS WITH TRIAL LENGTH AS DEPENDENT VARIABLE}

.regress trial_length jury_trial__patents_in_trial_defendants_in_trial

\begin{tabular}{|c|c|c|c|}
\hline Source & SS & $d f$ & $M S$ \\
\hline Model & 2049.51076 & 3 & 683.170252 \\
\hline Residual & 11563.4876 & 620 & 18.6507865 \\
\hline Total & 13612.9984 & 623 & 21.8507197 \\
\hline
\end{tabular}

\begin{tabular}{|c|c|}
\hline Number of obs & 624 \\
\hline $\mathrm{F}(3,620)$ & 36.63 \\
\hline Prob $>\mathrm{F}$ & 0 \\
\hline R-squared & 0.1506 \\
\hline AdjR-squared & 0.1464 \\
\hline RootMSE & 4.3187 \\
\hline
\end{tabular}

\begin{tabular}{|c|c|c|c|c|c|}
\hline trial_len h & Coef. & Std.Err. & $t$ & $P>|t|$ & [95\% Conf. Interval] \\
\hline jury_trial & 2.91791 & 0.398071 & 7.33 & 0 & 2.1361793 .699641 \\
\hline __patents 1 & 0.7974824 & 0.1130367 & 7.06 & 0 & 0.57550121 .019464 \\
\hline __defenda 1 & 0.4136399 & 0.1586138 & 2.61 & 0.009 & 0.10215460 .7251252 \\
\hline _cons & 3.527112 & 0.4813596 & 7.33 & 0 & 2.5818194 .472404 \\
\hline
\end{tabular}

.regress trial_length jury_trial_patents_in_trial_defendants_in_trial edtx ddel cdcal ndcal dmass dother additional_issues

\begin{tabular}{|c|c|c|c|}
\hline Source & SS & $d f$ & $M S$ \\
\hline Model & 3145.48955 & 9 & 349.498838 \\
\hline Residual & 10467.5089 & 614 & 17.04806 \\
\hline Total & 13612.9984 & 623 & 21.8507197 \\
\hline
\end{tabular}




\begin{tabular}{|c|c|}
\hline Numberofobs & 624 \\
\hline $\mathrm{F}(9,614)$ & 20.5 \\
\hline Prob>F & 0 \\
\hline R-squared & 0.2311 \\
\hline AdjR-squared & 0.2198 \\
\hline RootMSE & 4.1289 \\
\hline
\end{tabular}

\begin{tabular}{|c|c|c|c|c|c|}
\hline trial_len $h$ & Coef. & Std.Err. & $t$ & $P>|t|$ & [95\% Conf. Interval] \\
\hline jury_trial & 3.0421 & 0.3888019 & 7.82 & 0 & 2.2785583 .805643 \\
\hline __patents 1 & 0.8294364 & 0.1087359 & 7.63 & 0 & 0.6158971 .042976 \\
\hline __defenda 1 & 0.3818595 & 0.1520433 & 2.51 & 0.012 & $\begin{array}{l}0.0832715 \\
0.6804474\end{array}$ \\
\hline Edtx & -4.8225 & 0.9132535 & -5.28 & 0 & $\begin{array}{c}-6.615979- \\
3.029021\end{array}$ \\
\hline ddel & -3.258465 & 0.877902 & -3.71 & 0 & $-4.98252-1.53441$ \\
\hline cdcal & -2.840284 & 1.140161 & -2.49 & 0.013 & $\begin{array}{c}-5.079373- \\
0.601195\end{array}$ \\
\hline ndcal & 0.8272674 & 1.06259 & 0.78 & 0.437 & -1.2594842 .914019 \\
\hline dmass & (dropped) & & & & \\
\hline dother & -2.029112 & 0.8143683 & -2.49 & 0.013 & $\begin{array}{c}-3.628398- \\
0.4298274 \\
\end{array}$ \\
\hline additional & 0.5970442 & 0.7443868 & 0.8 & 0.423 & $\begin{array}{c}-0.8648086 \\
2.058897 \\
\end{array}$ \\
\hline _cons & 5.774669 & 0.8967826 & 6.44 & 0 & 4.0135367 .535802 \\
\hline
\end{tabular}

.regress trial_length_quartile_jury_trial__patents_in_trial__defendants_in_trial edtx ddel cdcal ndcal dmass dother additional_issues

\begin{tabular}{|c|c|c|c|}
\hline Source & SS & $d f$ & $M S$ \\
\hline Model & 159.729991 & 9 & 17.7477768 \\
\hline Residual & 605.255586 & 614 & 0.985758283 \\
\hline Total & 764.985577 & 623 & 1.22790622 \\
\hline
\end{tabular}




\begin{tabular}{|c|c|}
\hline Number of obs & 624 \\
\hline $\mathrm{F}(9,614)$ & 18 \\
\hline Prob $>\mathrm{F}$ & 0 \\
\hline R-squared & 0.2088 \\
\hline Adj R-squared & 0.1972 \\
\hline Root MSE & 0.99285 \\
\hline
\end{tabular}

\begin{tabular}{|c|c|c|c|c|c|}
\hline trial_len _ & Coef. & Std.Err. & $t$ & $P>|t|$ & [95\% Conf. Interval] \\
\hline jury_trial & 0.8974448 & 0.0934924 & 9.6 & 0 & 0.71384131 .081048 \\
\hline __patents $\sim 1$ & 0.1507489 & 0.0261469 & 5.77 & 0 & 0.09940070 .2020972 \\
\hline __defenda 1 & 0.0866565 & 0.0365607 & 2.37 & 0.018 & 0.01485720 .1584558 \\
\hline Edtx & -0.6660263 & 0.2196034 & -3.03 & 0.003 & $-1.097291-0.2347615$ \\
\hline Ddel & -0.2339763 & 0.2111027 & -1.11 & 0.268 & -0.64854710 .1805946 \\
\hline Cdcal & -0.4033284 & 0.2741663 & -1.47 & 0.142 & $-0.9417457 \quad 0.135089$ \\
\hline Ndcal & 0.488929 & 0.2555133 & 1.91 & 0.056 & $-0.0128569 \quad 0.990715$ \\
\hline Dmass & (dropped) & & & & \\
\hline Dother & -0.1099155 & 0.1958252 & -0.56 & 0.575 & $\begin{array}{lll}-0.4944839 & 0.2746529 \\
\end{array}$ \\
\hline additional & 0.0850569 & 0.1789973 & 0.48 & 0.635 & $-0.2664643 \quad 0.436578$ \\
\hline _cons & 1.697758 & 0.2156428 & 7.87 & 0 & 1.2742712 .121245 \\
\hline
\end{tabular}


REPEATS OF THE REGRESSIONS IN APPENDIX B,

BUT WITH “PATENTS PER THOUSAND PEOPLE” ADDED AS AN INDEPENDENT VARIABLE

.regress trial_length jury_trial__patents_in_trial__defendants_in_trial patents_per_thousand_people

\begin{tabular}{|c|c|c|c|}
\hline Source & SS & $d f$ & $M S$ \\
\hline Model & 2624.3169 & 4 & 656.079226 \\
\hline Residual & 10988.6815 & 619 & 17.7523126 \\
\hline Total & 13612.9984 & 623 & 21.8507197 \\
\hline
\end{tabular}

\begin{tabular}{|c|c|}
\hline Number of obs & 624 \\
\hline $\mathrm{F}(4,619)$ & 36.96 \\
\hline Prob>F & 0 \\
\hline R-squared & 0.1928 \\
\hline Adj R-squared & 0.1876 \\
\hline Root MSE & 4.2133 \\
\hline
\end{tabular}

\begin{tabular}{|c|c|c|c|c|c|}
\hline trial_len h & Coef. & Std.Err. & $t$ & $P>|t|$ & [95\% Conf. Interval] \\
\hline jury_trial & 3.00058 & 0.3886361 & 7.72 & 0 & 2.2373753 .763785 \\
\hline _patents 1 & 0.8047 & 0.1102877 & 7.3 & 0 & 0.58811671 .021283 \\
\hline _defenda 1 & 0.4047019 & 0.1547541 & 2.62 & 0.009 & 0.10079520 .7086085 \\
\hline patents_pe & 0.8746775 & 0.1537145 & 5.69 & 0 & 0.57281251 .176543 \\
\hline _cons & 1.976835 & 0.5429274 & 3.64 & 0 & 0.91063213 .043038 \\
\hline
\end{tabular}

.regress trial_length jury_trial__patents_in_trial__defendants_in_trial patents_per_thousand_people edtx ddel cdcal ndcal dmass dother additional_issues

\begin{tabular}{|c|c|c|c|}
\hline Source & SS & $d f$ & $M S$ \\
\hline Model & 3158.57381 & 10 & 315.857381 \\
\hline Residual & 10454.4246 & 613 & 17.0545262 \\
\hline Total & 13612.9984 & 623 & 21.8507197 \\
\hline
\end{tabular}

\begin{tabular}{|c|c|}
\hline Number of obs & 624 \\
\hline $\mathrm{F}(10,613)$ & 18.52 \\
\hline
\end{tabular}




\begin{tabular}{|c|c|}
\hline Prob $>F$ & 0 \\
\hline R-squared & 0.232 \\
\hline Adj R-squared & 0.2195 \\
\hline Root MSE & 4.1297 \\
\hline
\end{tabular}

\begin{tabular}{|c|c|c|c|c|c|}
\hline trial_len $h$ & Coef. & Std.Err. & $t$ & $P>|t|$ & [95\% Conf. Interval] \\
\hline jury_trial & 3.050881 & 0.3890048 & 7.84 & 0 & 2.2869373 .814824 \\
\hline _patents $\sim 1$ & 0.8356528 & 0.1089879 & 7.67 & 0 & 0.62161791 .049688 \\
\hline _defenda 1 & 0.3878576 & 0.1522262 & 2.55 & 0.011 & 0.08890940 .6868057 \\
\hline patents_pe & 0.3121257 & 0.3563483 & 0.88 & 0.381 & -0.38768581 .011937 \\
\hline edtx & -1.803608 & 0.9747163 & -1.85 & 0.065 & -3.7177960 .1105801 \\
\hline ddel & -0.6617432 & 0.964104 & -0.69 & 0.493 & -2.5550911 .231604 \\
\hline cdcal & $($ dropped) & & & & \\
\hline ndcal & 2.298423 & 1.910281 & 1.2 & 0.229 & -1.4530656 .049912 \\
\hline dmass & 2.475019 & 1.214234 & 2.04 & 0.042 & 0.09045624 .859581 \\
\hline dother & 0.6969727 & 0.8671899 & 0.8 & 0.422 & -1.0060512 .399996 \\
\hline additional & 0.5905773 & 0.7445646 & 0.79 & 0.428 & -0.87162942 .052784 \\
\hline _cons & 2.54928 & 1.036234 & 2.46 & 0.014 & 0.51428194 .584278 \\
\hline
\end{tabular}




\section{APPENDIX C:}

\begin{tabular}{|c|c|c|c|c|}
\hline District & $\begin{array}{c}\text { Total } \\
\text { Population }\end{array}$ & $\begin{array}{c}\text { Number of } \\
\text { Patents in the } \\
\text { 1990s }\end{array}$ & $\begin{array}{c}\text { Number of Patents } \\
\text { Cumulative (over all } \\
\text { time) }\end{array}$ & $\begin{array}{c}\text { 1990s Patents per } \\
10,000 \\
\text { population }\end{array}$ \\
\hline CAND Totals: & 7388948.00 & 40832.00 & 72490.00 & 55.26 \\
\hline NYWD Totals: & 2715695.00 & 11345.00 & 23907.00 & 41.78 \\
\hline IDD Totals: & 1112950.00 & 3694.00 & 4718.00 & 33.19 \\
\hline VTD Totals: & 359831.00 & 1092.00 & 1760.00 & 30.35 \\
\hline MIED Totals: & 6218621.00 & 16900.00 & 38882.00 & 27.18 \\
\hline CTD Totals: & 3405565.00 & 8726.00 & 23779.00 & 25.62 \\
\hline MND Totals: & 4474754.00 & 11259.00 & 22304.00 & 25.16 \\
\hline NYND Totals: & 3155204.00 & 7336.00 & 17849.00 & 23.25 \\
\hline MAD Totals: & 6575368.25 & 15217.75 & 35488.25 & 23.14 \\
\hline TXND Totals: & 7735042.00 & 17809.00 & 32090.00 & 23.02 \\
\hline COD Totals: & 3918709.00 & 8935.00 & 17078.00 & 22.80 \\
\hline PAED Totals: & 4350439.20 & 9325.50 & 24523.30 & 21.44 \\
\hline WIED Totals: & 2918923.50 & 5788.00 & 14155.50 & 19.83 \\
\hline ILND Totals: & 9760932.00 & 19179.00 & 53332.00 & 19.65 \\
\hline CASD Totals: & 15318152.00 & 29717.00 & 70066.00 & 19.40 \\
\hline OKND Totals: & 935437.00 & 1813.00 & 7385.00 & 19.38 \\
\hline DED Totals: & 1705407.50 & 3277.00 & 8650.75 & 19.22 \\
\hline WAWD Totals: & 4652017.75 & 8866.25 & 17152.25 & 19.06 \\
\hline OHSD Totals: & 5024564.00 & 9121.25 & 21971.25 & 18.15 \\
\hline UTD Totals: & 2117076.00 & 3823.00 & 7345.00 & 18.06 \\
\hline LAMD Totals: & 699220.00 & 1183.00 & 2996.00 & 16.92 \\
\hline AZD Totals: & 4935585.00 & 8120.00 & 15325.00 & 16.45 \\
\hline NYSD Totals: & 6718833.00 & 11002.00 & 29435.00 & 16.37 \\
\hline TXSD Totals: & 6828439.00 & 11163.00 & 26640.00 & 16.35 \\
\hline OHND Totals: & 5431011.67 & 8798.33 & 26731.00 & 16.20 \\
\hline INSD Totals: & 3172461.00 & 5139.00 & 13209.00 & 16.20 \\
\hline NJD Totals: & 20677307.30 & 32816.50 & 91224.95 & 15.87 \\
\hline INND Totals: & 1668179.00 & 2630.00 & 7046.00 & 15.77 \\
\hline ORD Totals: & 3206105.25 & 5043.75 & 9580.75 & 15.73 \\
\hline WIWD Totals: & 1445683.50 & 2263.00 & 4503.50 & 15.65 \\
\hline
\end{tabular}




\begin{tabular}{|c|c|c|c|c|}
\hline NHD Totals: & 894665.00 & 1330.00 & 2594.00 & 14.87 \\
\hline NYED Totals: & 18309939.00 & 27051.00 & 75258.00 & 14.77 \\
\hline DCD Totals: & 1201401.25 & 1677.25 & 3850.00 & 13.96 \\
\hline MIWD Totals: & 2862711.00 & 3900.00 & 10342.00 & 13.62 \\
\hline IASD Totals: & 1639972.00 & 2148.00 & 4837.50 & 13.10 \\
\hline MDD Totals: & 4313179.50 & 5516.00 & 12981.25 & 12.79 \\
\hline IAND Totals: & 786645.00 & 998.00 & 2751.00 & 12.69 \\
\hline FLSD Totals: & 5646636.00 & 6973.00 & 14213.00 & 12.35 \\
\hline ILCD Totals: & 1859278.80 & 2295.30 & 6369.00 & 12.35 \\
\hline NCED Totals: & 2750154.00 & 3316.00 & 5537.00 & 12.06 \\
\hline PAWD Totals: & 4009223.33 & 4707.67 & 15129.00 & 11.74 \\
\hline NMD Totals: & 1711849.00 & 1987.00 & 3945.00 & 11.61 \\
\hline CACD Totals: & 4656014.00 & 5358.00 & 11136.00 & 11.51 \\
\hline TNED Totals: & 2273632.00 & 2616.00 & 6129.00 & 11.51 \\
\hline GAND Totals: & 4842046.00 & 5424.00 & 9766.00 & 11.20 \\
\hline VAED Totals: & 5070771.50 & 5569.50 & 12843.00 & 10.98 \\
\hline KYWD Totals: & 2310813.50 & 2534.25 & 6243.75 & 10.97 \\
\hline PAMD Totals: & 2785507.00 & 2987.00 & 7770.00 & 10.72 \\
\hline RID Totals: & 1187247.75 & 1271.25 & 2631.75 & 10.71 \\
\hline MOED Totals: & 3117968.70 & 3186.70 & 7411.00 & 10.22 \\
\hline NCMD Totals: & 3586107.00 & 3635.50 & 7012.00 & 10.14 \\
\hline OKWD Totals: & 1579783.00 & 1574.00 & 4429.00 & 9.96 \\
\hline VAWD Totals: & 1450069.00 & 1403.00 & 3423.50 & 9.68 \\
\hline WAED Totals: & 1093508.00 & 1032.00 & 2424.00 & 9.44 \\
\hline NCWD Totals: & 1858759.00 & 1742.50 & 3870.00 & 9.37 \\
\hline FLND Totals: & 1288730.00 & 1111.00 & 2422.00 & 8.62 \\
\hline MTD Totals: & 578166.00 & 465.00 & 856.00 & 8.04 \\
\hline SCD Totals: & 3415545.00 & 2723.00 & 6023.00 & 7.97 \\
\hline NED Totals: & 1048670.50 & 815.00 & 1842.50 & 7.77 \\
\hline KYED Totals: & 1014317.50 & 781.00 & 1763.00 & 7.70 \\
\hline TNWD Totals: & 1518855.00 & 1151.00 & 2204.00 & 7.58 \\
\hline NVD Totals: & 1917027.00 & 1395.00 & 2609.00 & 7.28 \\
\hline FLMD Totals: & 8696343.00 & 6276.00 & 12817.00 & 7.22 \\
\hline KAD Totals: & 2424276.50 & 1719.00 & 4408.00 & 7.09 \\
\hline
\end{tabular}




\begin{tabular}{|c|c|c|c|c|}
\hline WYD Totals: & 331612.00 & 233.00 & 563.00 & 7.03 \\
\hline WVSD Totals: & 777237.00 & 537.00 & 1739.00 & 6.91 \\
\hline ILSD Totals: & 278508.00 & 190.00 & 351.00 & 6.82 \\
\hline ALND Totals: & 2454089.00 & 1576.00 & 4235.00 & 6.42 \\
\hline MOWD Totals: & 2169280.50 & 1388.00 & 3397.00 & 6.40 \\
\hline MSND Totals: & 555587.00 & 346.00 & 700.00 & 6.23 \\
\hline NDD Totals: & 351678.00 & 216.00 & 519.00 & 6.14 \\
\hline CAED Totals: & 6268054.00 & 3846.00 & 8072.00 & 6.14 \\
\hline TXED Totals: & 1561689.00 & 888.00 & 2267.00 & 5.69 \\
\hline LAED Totals: & 1684629.00 & 929.00 & 2639.00 & 5.51 \\
\hline AKD Totals: & 461020.00 & 250.00 & 442.00 & 5.42 \\
\hline TXWD Totals: & 3386373.00 & 1821.00 & 3835.00 & 5.38 \\
\hline TNMD Totals: & 1823310.00 & 912.00 & 1810.00 & 5.00 \\
\hline SDD Totals: & 513647.00 & 255.00 & 622.00 & 4.96 \\
\hline ALSD Totals: & 588816.00 & 290.00 & 568.00 & 4.93 \\
\hline MED Totals: & 894980.00 & 416.00 & 1028.00 & 4.65 \\
\hline LAWD Totals: & 1755831.00 & 814.00 & 2094.00 & 4.64 \\
\hline WVND Totals: & 534023.25 & 246.75 & 654.75 & 4.62 \\
\hline ARWD Totals: & 911997.00 & 408.50 & 820.50 & 4.48 \\
\hline MSSD Totals: & 1477904.00 & 591.00 & 1236.00 & 4.00 \\
\hline GAMD Totals: & 1399105.00 & 554.00 & 1244.00 & 3.96 \\
\hline ALMD Totals: & 858602.00 & 339.00 & 675.00 & 3.95 \\
\hline GASD Totals: & 1264849.00 & 476.00 & 949.00 & 3.76 \\
\hline ARED Totals: & 1194892.00 & 442.50 & 998.50 & 3.70 \\
\hline OKED Totals: & 281739.00 & 99.00 & 281.00 & 3.51 \\
\hline HID Totals: & 1211390.00 & 419.00 & 882.00 & 3.46 \\
\hline
\end{tabular}


